\title{
VARIABILITY OF OXYGEN-THERMAL CONDITIONS IN SELECTED LAKES IN POLAND
}

\author{
ZMIENNOŚĆ WARUNKÓW TLENOWO-TERMICZNYCH \\ WYBRANYCH JEZIOR W POLSCE
}

\begin{abstract}
Dissolved oxygen in water (DO) is one of the primary parameters determining its quality. It remains in close relation to water temperature. The article presents results of DO and water temperature measurements performed for five stratified lakes in Poland in the years 2007-2014. The measurements were performed with monthly frequency in the summer half-year (May-October) in the deepest place of each of the lakes. The compared data show the complex character of the course of both of the parameters. The analysis of depth profiles revealed the prevalence of a decreasing tendency, or no tendency was recorded - both in the case of DO and water temperature. Due to the incoherent character of the water in the case of stratified lakes, a more detailed comparison was performed, referring to changes occurring in zones developed during summer stratification. It was determined that the temperature of the epilimnion was directly dependent on air temperature, and in all cases it showed an increasing tendency. Simultaneously, along with an increase in temperature, in the majority of cases, DO concentration in the zone decreased. In reference to the waters of the hypolimnion, increasing, decreasing, and no tendencies were recorded. The above distribution is determined by individual factors of the lakes morphometry, trophic status, groundwater alimentation, etc. Several years of measurements of DO and water temperature in depth profiles of several lakes in Poland constitute valuable information on the current transformations of the environment of this part of Europe. In the future, the information can provide the basis for long-term analyses over the next decades, enriching global knowledge on those parameters of key importance for water ecosystems.
\end{abstract}

Keywords: oxygen dissolved, temperature water, climate change, lakes

\section{Introduction}

Oxygen is the most important gas in waters. Its presence determines not only the life functions of plants and animals, but also the general circulation of organic and inorganic matter. Dissolved oxygen in water (DO - dissolved oxygen) is one of the primary parameters determining its quality [1]. In lakes, oxygen is used among others for the mineralisation of organic matter. Therefore, in situations of a high trophic status of lakes, its deficits may occur. The content of DO influences the conditions of circulation of carbon,

\footnotetext{
${ }^{1}$ Institute of Physical Geography and Environmental Planning, Adam Mickiewicz University, ul. Dzięgielowa 27, 61-680 Poznań, Poland

${ }^{2}$ Institute of Meteorology and Water Management - National Research Institute, ul. Podleśna 61, 01-673 Warszawa, Poland

*Corresponding author: marp114@wp.pl
} 
nitrogen, phosphorus, iron, and manganese in the water mass [2]. DO remains in close relations to water temperature - its solubility decreases with temperature increase. In extreme cases, in the summer period, oxygen deficits may cause so-called oxygen squeeze, ie dying of aerobic organisms. DO and water temperature are important in the implementation of the Framework Water Directive aimed at the improvement and maintenance of the quality of European waters [3]. The concentration and distribution of oxygen in lakes depends on a number of factors, related among others to the trophic status and water pollution, morphometry, climatic conditions, intensity of biological processes, etc. The observed climatic changes, and particularly successive increase in air temperature, have consequences in the functioning of lake ecosystems. Numerous papers from many regions of the world show the correlation of warming with the course of physical and chemical $[4,5]$ and biological processes [6-8] in lakes. Also in the case of lakes in Poland, a considerable effect of climate changes on their functioning was recorded [9-11]. In reference to changes in water temperatures in lakes, i.e. one of its basic parameters, a need exists to expand systematic observations of deeper sectors of lakes - particularly in the context of a larger group of objects for the purpose of a more complete understanding of the occurring thermal changes in the lakes of Central Europe. The gap can be successively filled by observations conducted over the last several years by the Institute of Meteorology and Water Management - State Research Institute (IMGW-PIB).

The objective of the paper is to analyse changes in oxygen-thermal conditions of five lakes located in various parts of northern Poland in the years 2007-2014, and to identify tendencies and correlations occurring between water temperature and oxygenation and meteorological conditions and morphometric parameters of lakes.

\section{Research methods}

The paper employed data concerning $D O\left[\mathrm{mgO}_{2} \cdot \mathrm{dm}^{-3}\right]$ and water temperature $T\left[{ }^{\circ} \mathrm{C}\right]$ measurements for five lakes in northern Poland (Fig. 1). Their morphometric characteristics are presented in Table 1.

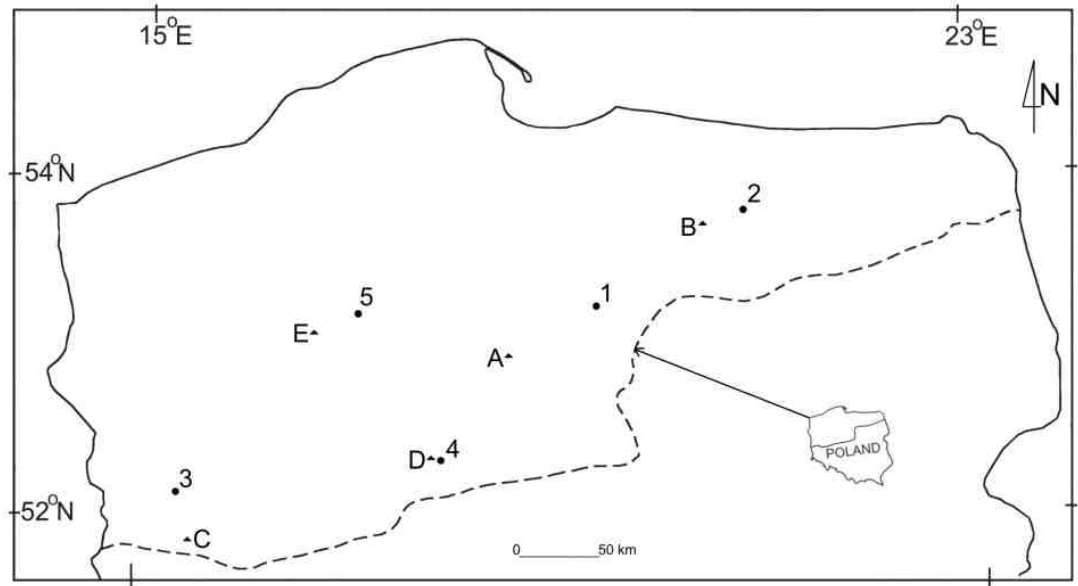

Fig. 1. Location of study objects: 1 - Bachotek, 2 - Dadaj, 3 - Nieslysz, 4 - Powidzkie, 5 - Slawianowskie. Meteorological stations: A - Torun, B - Olsztyn, C - Zielona Gora, D - Powidz, E - Pila, Dotted line - maximum range of the last glaciation 
Morphometric data of the studied lakes

\begin{tabular}{|c|c|c|c|c|c|}
\hline No & Lake & $\begin{array}{c}\text { Area } \\
{[\mathbf{h a}]}\end{array}$ & $\begin{array}{c}\text { Volume } \\
{\left[\mathbf{1 0}^{\mathbf{6}} \mathbf{~ m}^{\mathbf{3}}\right]}\end{array}$ & $\begin{array}{c}\text { Depth } \\
\text { max [m] }\end{array}$ & $\begin{array}{c}\text { Depth } \\
\text { mean }[\mathbf{m}]\end{array}$ \\
\hline 1 & Bachotek & 215.0 & 15.3 & 24.3 & 7.2 \\
\hline 2 & Dadaj & 975.0 & 120.7 & 39.8 & 12.0 \\
\hline 3 & Nieslysz & 526.0 & 34.4 & 34.7 & 6.9 \\
\hline 4 & Powidzkie & $1,097.5$ & 134.7 & 46.0 & 11.5 \\
\hline 5 & Slawianowskie & 269.0 & 18.3 & 15.0 & 6.6 \\
\hline
\end{tabular}

DO and water temperature measurements performed in the years 2007-2014 were performed in the warm half-year, i.e. from May to October - each time in each of the months (210 times in total). The measurements were performed every $1 \mathrm{~m}$ in the deepest place of each of the lakes. This permitted obtaining very detailed data concerning the distribution of both of the parameters (for example for Lake Bachotek in the analysed multiannual, 2016 records were taken). The measurements were performed by means of YSI Professional and YSI ProOdo sondes.

In the case of Poland, the majority of lakes are located in its northern part. This has to do with the range of the last glaciation. Lakes considered in the paper are also located within the range (Fig. 1). Moreover, the paper employed information concerning air temperature (www.tutiempo.com) for a given month in which measurements were performed in the lakes. The location of meteorological stations is also presented in Figure 1.

All of the analyses and statistical calculations were performed in computing environment $\mathbf{R}$ version 3.3.1 (2016-06-21). If not specified otherwise, results of all significance tests are evaluated in comparison to the customarily adopted level of $\alpha=0.05$. The analysis of trends related to the development of mean annual temperatures and oxygen content applied a Mann-Kendall test for a time series determined by the Yue-Pilon method. This permitted the elimination of potential disturbances related to the autocorrelation of time series. The slope of the regression line was determined by means of a Theil-Sen resistant estimator [12]. Implementation of the techniques available in zyp package for $\mathbf{R}$ environment was applied [13]. Box-plots were applied for comparisons between groups.

\section{Results and discussion}

The analysis of changes in oxygen-thermal conditions discussed in the paper was conducted twofold. At the first stage, the distribution of DO and water temperature was analysed for particular months of the summer half-year. In the second approach, changes concerning both of the characteristics in the years 2007-2014 were determined.

Based on the performed analyses, the mean highest concentration of DO in water (as the mean from the entire profile in the analysed multiannual) was recorded in Lake Powidzkie $6.1 \mathrm{mg} \mathrm{O}_{2} \cdot \mathrm{dm}^{-3}$, and the lowest in Lake Bachotek $-3.0 \mathrm{mg} \mathrm{O} \mathrm{O}_{2} \cdot \mathrm{dm}^{-3}$. In the monthly distribution, the highest DO value was recorded in May 2011 for Lake Powidzkie: $11.8 \mathrm{mg} \mathrm{O} \mathrm{O}_{2} \cdot \mathrm{dm}^{-3}$, and the lowest in August for Lake Dadaj: $1.2 \mathrm{mg} \mathrm{O}_{2} \cdot \mathrm{dm}^{-3}$. The highest variability of $D O$ for the same months in the analysed period was recorded for October for Lake Dadaj - the difference amounted to $6.3 \mathrm{mg} \mathrm{O}_{2} \cdot \mathrm{dm}^{-3}$. 
may june july august september october average
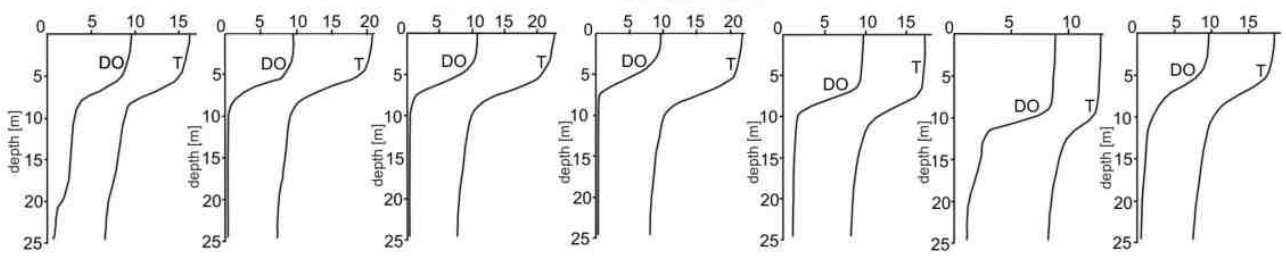

Dadaj Lake
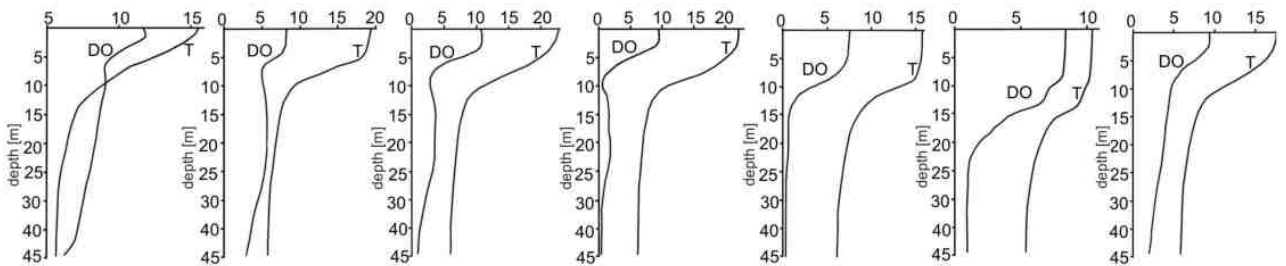

Nieslysz Lake
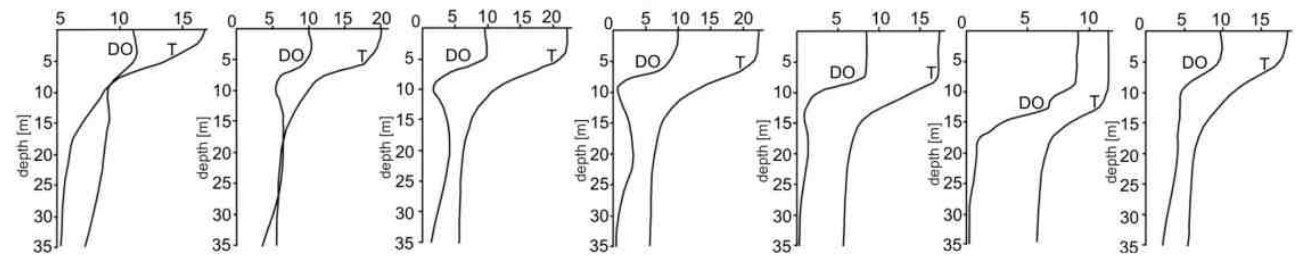

Powidzkie Lake
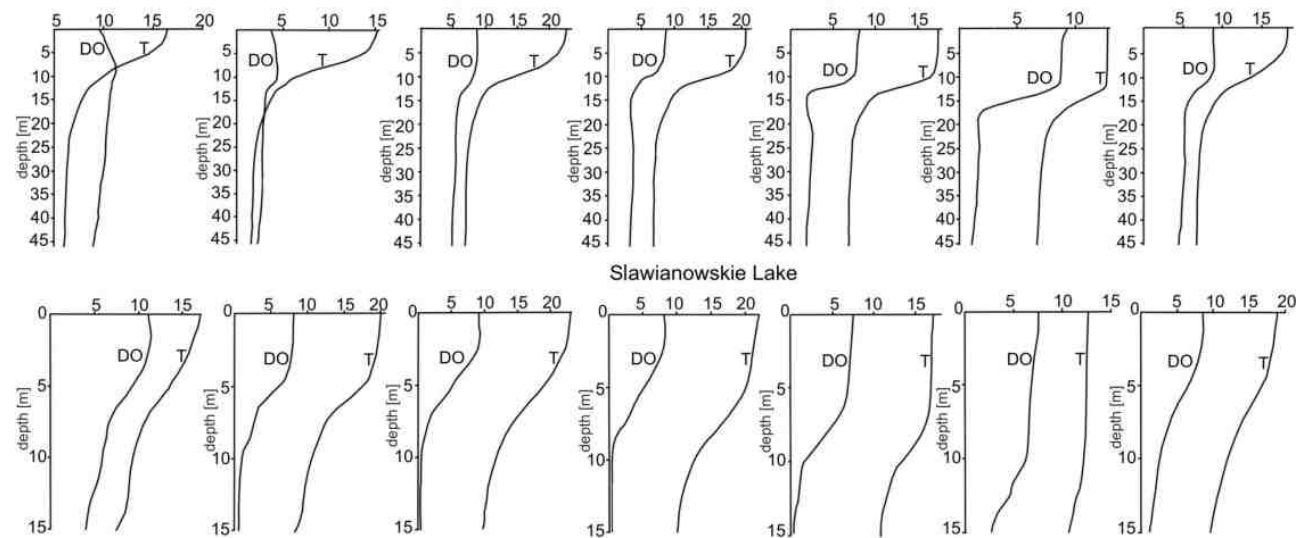

Slawianowskie Lake

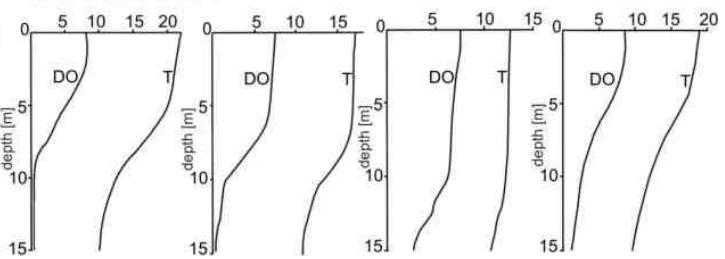

Fig. 2. The course of oxygen concentration and water temperature of the analysed lakes (mean monthly values and means for the entire analysed period) in the years 2007-2014, DO - dissolved oxygen $\left[\mathrm{mgO}_{2} \cdot \mathrm{dm}^{-3}\right], T$ - temperature $\left[{ }^{\circ} \mathrm{C}\right]$

The highest water temperature occurred in Lake Slawianowskie $14.0^{\circ} \mathrm{C}$ and the lowest in Lakes Dadaj and Nieslysz: $8.9^{\circ} \mathrm{C}$. In the monthly cycle, the highest value was recorded for Lake Slawianowskie, in August 2007 amounting to $16.9^{\circ} \mathrm{C}$. The lowest mean monthly temperature was recorded in May 2013 for Lake Nieslysz - it amounted to $6.8^{\circ} \mathrm{C}$. The highest variability of water temperature for the same months in the analysed period was 
also recorded in October. The difference between the highest and lowest mean from the month amounted to $4.7^{\circ} \mathrm{C}$. It was determined for Lake Slawianowskie.

All of the lakes are dimictic, i.e. double mixing of the entire water mass occurs in them over a year: in spring, followed by the development of stratification lasting until autumn, when the entire cycle of mixing of the water mass is repeated. The comparison of measurements of the concentration of oxygen dissolved in water as well as water temperature in particular lakes is presented in Figure 2, and their distribution in Figure 3.
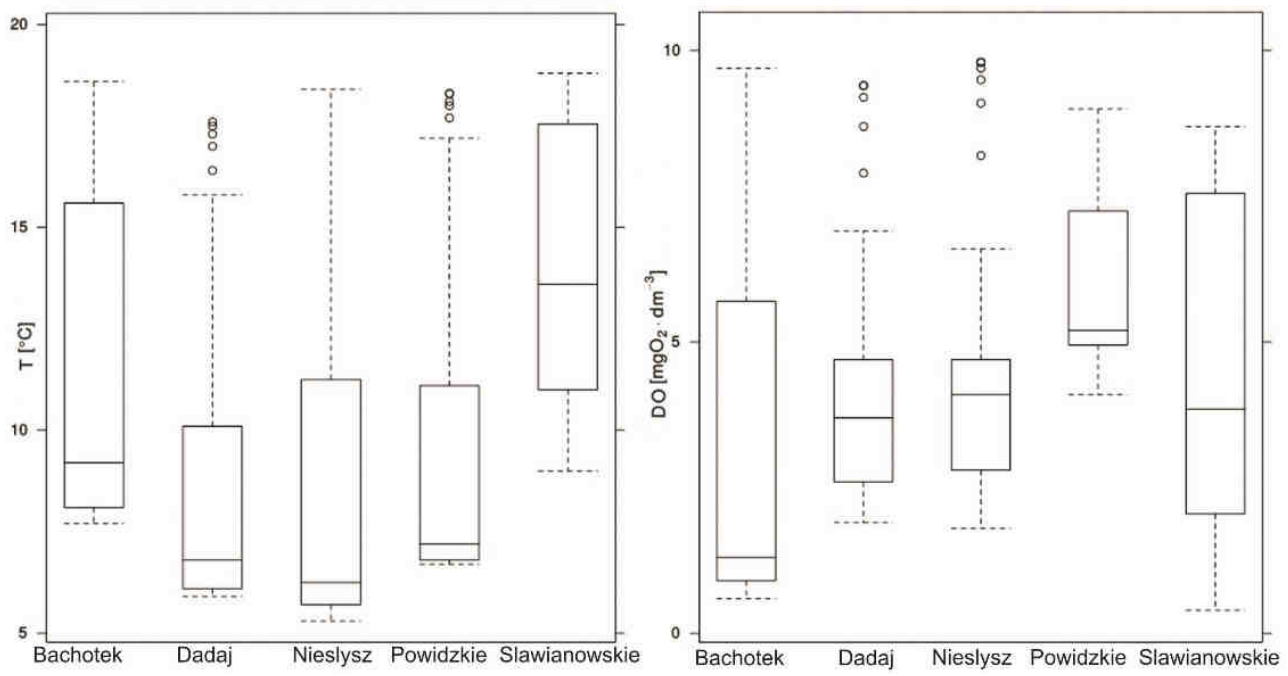

Fig. 3. Distribution of temperature and dissolved oxygen values. The thresholds of the box are designated by $1^{\text {st }}$ and $3^{\text {rd }}$ quartile, and the middle bar - the median. Whiskers designate thresholds $\pm 1.5 \mathrm{IQR}$ (difference between $1^{\text {st }}$ and $3^{\text {rd }}$ quartile) from the bottom and top of the box, or stop at the maximum/minimum observation. Observations exceeding thresholds designated by whiskers are marked with single points (outlier in relation to the entire distribution)

Curves of the $D O$ distribution in the majority of the analysed lakes take form of a clinograde, where the concentration of dissolved oxygen decreases with depth. A different situation was only observed in the case of $D O$ distribution in May and June in Lake Powidzkie. In May, the curve is approximate to a positive heterograde (where the maximum oxygen content occurs in the metalimnion as a result of wave action and movement of oxygen from the epilimnion), and in June the curve takes form approximate to an ortograde (no gradient).

The analysed lakes are distinguished by considerable oxygen deficit. The mean values obtained from measurement profiles suggest that the oxygen deficit varies from $48 \%$ (Lake Powidzkie) to $70 \%$ (Lake Bachotek). Among all of the analysed months, the lowest oxygen deficits were recorded in May - the lowest value was recorded in the case of Lake Powidzkie - 14.5\%. The highest deficits occurred in August - the highest value was recorded for Lake Dadaj, and amounted to $81.4 \%$.

Tendencies of changes in $D O$ in water and water temperature are presented in Figure 4. 

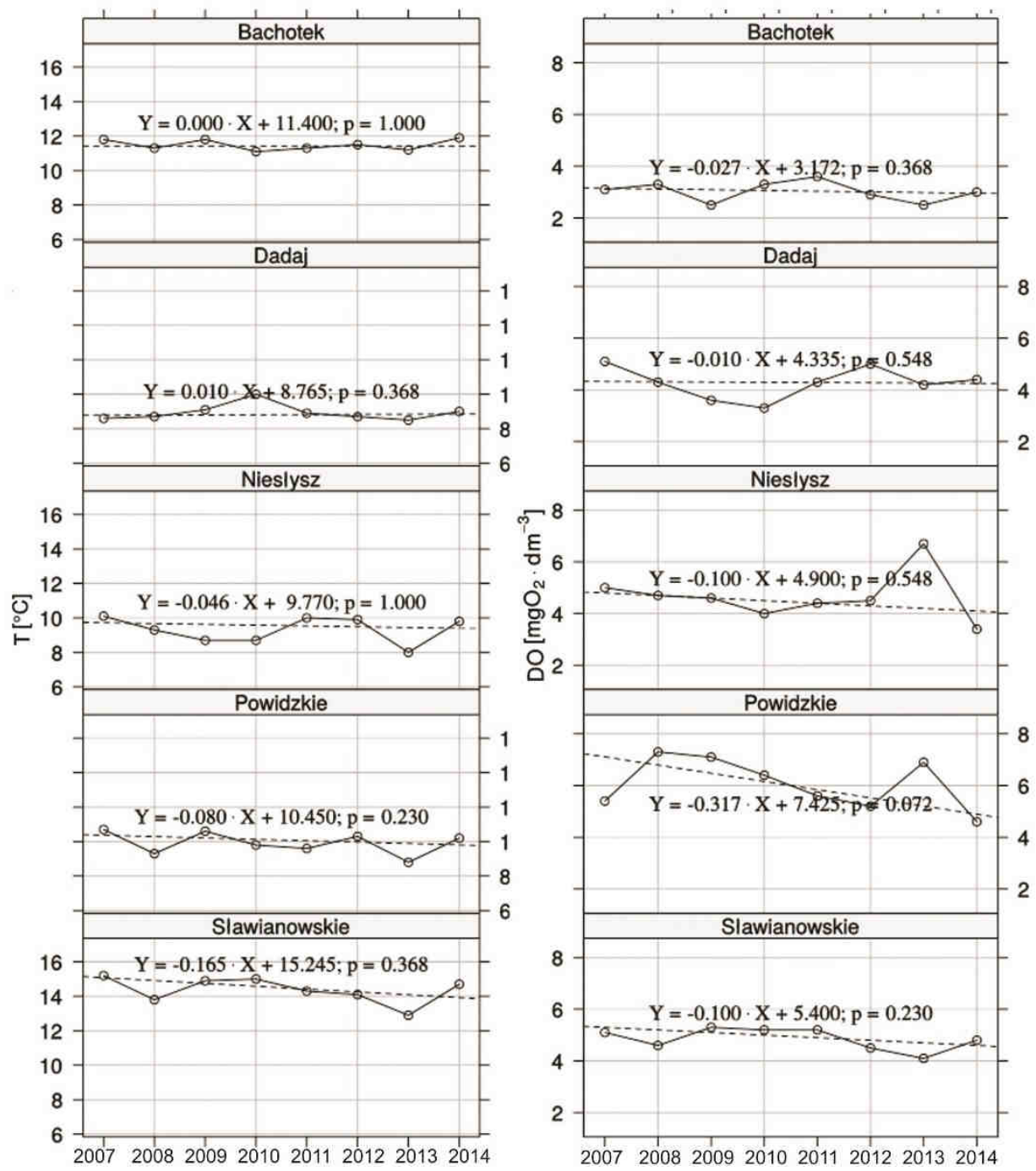

Fig. 4. Tendencies of changes in water temperatures and DO in lakes in the years 2007-2014 in the entire profile

Figure 4 shows that the course of both of the characteristics was not variable in reference to all of the analysed lakes. In the case of water temperature, a decreasing tendency was prevalent (although it was not statistically significant for any of the analysed lakes), as well as lack of any tendency. Similar results were obtained for changes in $D O$ decreasing tendencies prevailed (at no statistical significance), as well as lack of any trend.

The characteristic feature of the analysed lakes is the development of stratification, correlated with water temperature and the related density. In the period of summer stratification, the $D O$ concentration reflects the course of metabolic processes the best. The thickness of particular zones during stratification was determined as mean temperature in 
July and August for the entire study period. This provided the basis for the determination of the range of the epi-, meta (thermocline)-, and hypolimnion, and determination of tendencies of changes in water temperature and $D O$ in the zones (Fig. 5). Moreover, Figure 5 includes the course of the mean air temperature in July and August for meteorological stations the location of which is presented in Figure 1. The trend analysis is presented in Table 2.
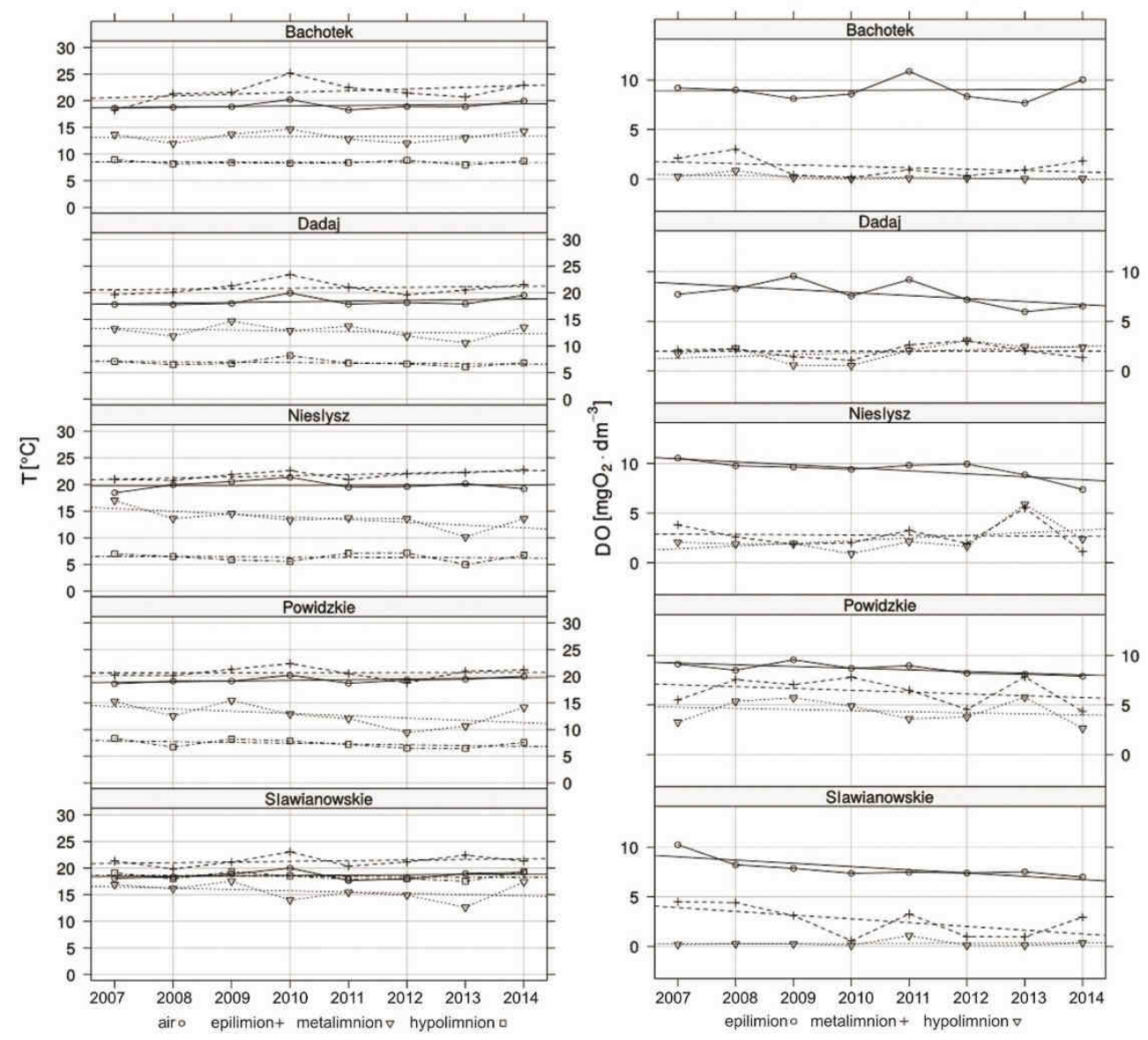

Fig. 5. Changes in water temperature and oxygen concentration in particular zones of the analysed lakes during summer stratification (July-August) in the years 2007-2014

Similarly as in the case of tendencies of changes in water temperature and $D O$ in the entire profile, also in reference to layers developed during summer stratification, differentiation of particular lakes is observed. In the case of temperature in the epilimnion, data from the years 2007-2014 suggest the prevalence of increasing tendency. The system generally refers to the distribution of air temperature, and the observed deviations result among others from higher thermal stability of water. In reference to the metalimnion, a decreasing tendency was prevalent - three of five lakes showed such a tendency. 
The observed trends were statistically significant only in the case of Lake Nieslysz (Table 2). The temperature of the waters of the hypolimnion in three cases showed no tendency, and in two cases the tendency was negative, although not statistically significant.

Table 2

Trend analysis $(N=8)$ concerning mean air and water temperatures (in three layers) and $D O$ in the period of summer stratification in the years from 2007 to 2014

\begin{tabular}{|c|c|c|c|c|c|}
\hline \multirow[b]{2}{*}{ Lake } & \multirow[b]{2}{*}{ Layer } & \multicolumn{2}{|c|}{$T\left[{ }^{\circ} \mathbf{C}\right]$} & \multicolumn{2}{|c|}{$D O\left[\mathrm{mg} \mathrm{O}_{2} \cdot \mathrm{dm}^{-3}\right]$} \\
\hline & & $\begin{array}{c}\text { Tilt a regression } \\
\text { line }\end{array}$ & $p$ & $\begin{array}{c}\text { Tilt a regression } \\
\text { line }\end{array}$ & $p$ \\
\hline \multirow{4}{*}{ Bachotek } & Air & 0.080 & 0.368 & & \\
\hline & Epilimion & 0.274 & 0.764 & -0.142 & 1.000 \\
\hline & Metalimnion & 0.063 & 0.548 & -0.035 & 0.548 \\
\hline & Hypolimion & -0.016 & 0.764 & -0.032 & 0.133 \\
\hline \multirow{4}{*}{ Dadaj } & Air & 0.060 & 0.368 & & \\
\hline & Epilimion & 0.156 & 1.000 & -0.287 & 0.072 \\
\hline & Metalimnion & -0.175 & 0.548 & -0.016 & 1.000 \\
\hline & Hypolimion & -0.058 & 1.000 & 0.111 & 0.548 \\
\hline \multirow{4}{*}{ Nieslysz } & Air & -0.024 & 0.368 & & \\
\hline & Epilimion & 0.238 & 0.072 & -0.213 & 0.368 \\
\hline & Metalimnion & -0.360 & 0.016 & -0.157 & 0.764 \\
\hline & Hypolimion & -0.084 & 1.000 & 0.080 & 0.368 \\
\hline \multirow{4}{*}{ Powidzkie } & Air & 0.146 & 0.133 & & \\
\hline & Epilimion & 0.116 & 0.764 & -0.180 & $\mathbf{0 . 0 3 5}$ \\
\hline & Metalimnion & -0.727 & 0.548 & -0.176 & 0.230 \\
\hline & Hypolimion & -0.143 & 0.368 & -0.163 & 0.230 \\
\hline \multirow{4}{*}{ Slawianowskie } & Air & 0.146 & 0.548 & & \\
\hline & Epilimion & 0.135 & 0.230 & -0.205 & 0.133 \\
\hline & Metalimnion & -0.380 & 0.230 & -0.345 & 0.133 \\
\hline & Hypolimion & -0.140 & 0.368 & 0.001 & 1.000 \\
\hline
\end{tabular}

$p$ - trend significance

Changes in $D O$ in the epilimnion zone showed a negative tendency in four cases. The observed trends were statistically significant only in the case of Lake Powidzkie (Table 2). Only in the case of Lake Bachotek no tendency was recorded. Lack of a decreasing tendency of $D O$ at a simultaneous increase in water temperature can be caused by very intensive processes of photosynthesis. The layer of metalimnion showed a decrease in $D O$ in three cases, and no tendency was recorded in the remaining two. The deepest zones of the lakes including the hypolimnion were also diversified in such terms - in two cases no tendency of changes was recorded, in two cases the tendency was increasing, and in one case - decreasing, although they were not statistically significant.

The analysis of changes in oxygen-thermal conditions for five lakes in Poland, presented in the paper, shows the complexity of the issue. Changes in temperature dynamics of the surface water layers are directly dependent on climatic factors, and in the majority of analysed cases they showed an increasing tendency. Such a state is in accordance with the current studies concerning this zone of lakes. The analysis of approximately a dozen lakes in Poland in the years 1961-2010 showed that warming of the surface water layers in lakes is particularly evident in spring (April, May) and summer months (July, August), where e.g. in the case of Lake Lubie, in May an increase by $1.02^{\circ} \mathrm{C}$ per decade was recorded [14]. A similar situation was observed in the case of lakes 
analysed in Estonia [15]. An increase in surface water temperature is also in accordance with that in other lakes in Europe [16-18] as well as in other regions of the world [19, 20].

A more complicated course concerns water temperature in deeper parts of lakes. The temperature of hypolimnion waters can be subject to both warming and cooling, and the changes depend on the morphometry and season of the year [18]. In the analysed cases, the temperature of the hypolimnion showed no tendency, or the tendency was decreasing. The results generally refer to earlier studies of the type in Poland [21]. This fact can be accounted for by groundwater alimentation, in the case of the analysed lakes requiring more detailed research in the future in order to verify the thesis.

The observed climatic changes will have consequences in the functioning of lake ecosystems [22]. This statement can be referred both to biotic and abiotic aspects. The element combining both of the issues is the content of oxygen in water, showing a strong correlation with its temperature.

In reference to DO, the highest differences in its vertical distribution occur in the period of summer thermal stratification, due to the isolation of the lower water masses. The developed thermocline layer constitutes a barrier for movement of oxygen between the epi- and hypolimnion [23]. A more rapid increase in water temperature will contribute to the accelerated development of summer stratification, and therefore to a longer term of using up oxygen (by living organisms and mineralisation processes) at a simultaneous lack of possibility of its supply to the deepest parts of the lakes. Factors responsible for the observed oxygen deficits are not solely related to natural processes in the form of climatic changes. An increase in human activity in the catchment and increasingly extensive adaptation of lakes for various economic purposes result in a successive change of their trophic status. Oxygen concentration over a period of several decades was disturbed as a result of anthropopressure. This contributed to strong eutrophication, causing increasingly frequently observed in many lakes algal blooms - using oxygen for breathing, which is then necessary for their decomposition [24]. The effect of anthropopressure can change the trophic status of lakes, even those resistant to degradation over a period of several years [25]. Lake sediments are a particular threat to lakes. In certain conditions, elements contained in the sediments can pollute the water depths [26]. Due to biogene compounds deposited in bottom sediments, even in the case of naturalisation of external sources of threats, the ecological state of a given lake does not always improve. An example of such a situation is Lake Goreckie (in the Wielkopolski National Park). Its trophic status is maintained on a high level [27]. In the case of exhausting oxygen resources in the hypolimnion, increased release of phosphorus compounds from bottom sediments is observed, followed by increased production of organic substance in the next season in the surface water layer [28]. Therefore, a frequently applied solution for reclamation of lakes is artificial aeration of near-bottom waters which as a result of oxygen supply is supposed to hinder secondary supply of biogenes to the water mass. Due to the morphometric variability and the related water mixing system, the lakes can respond in different ways to climatic factors in various regions [29] as well as in the same climatic zone [30]. The course of changes in oxygen in the analysed lakes in the deepest water layer turned out to be variable. As indicated above, it was dependent on not only climatic parameters (similar within the discussed area for all of the lakes), but also morphometric and local parameters (land use in the catchment). The differences declined in the situation of distribution of dissolved oxygen in the entire profile. 
Research on water quality (in accordance to the assumptions of the Framework Water Directive) conducted in recent years by particular agendas of Provincial Inspectorates for Environmental Protection showed that three of the analysed lakes (Powidzkie, Nieslysz, and Dadaj) were distinguished by good (class II), and the two remaining ones (Slawianowskie and Bachotek) by moderate ecological status (class III). The worst ecological status was recorded for two lakes with the lowest maximum depth. The most unfavourable parameters in these terms are those of Lake Slawianowskie. Next to the lowest depth among the cases studied in the paper, it is also distinguished by a substantial contribution of agricultural land (more than $80 \%$ ) in the direct catchment.

\section{Conclusions}

The distribution and changes in DO and temperature in thermal profiles presented in the paper suggest their complex course. In view of maintaining the current tendencies of climatic changes, many components of the environment will be subject to transformation of the current parameters. Lakes are considered to be exceptionally prone to such changes. Due to the string correlations of atmosphere with surface waters, the response of the latter to changes in air temperature is obvious. Analyses of changes in temperature in the entire study profiles in the deepest places of the lakes showed, however, that in such a system they show a decreasing or no tendency. The fact was related to the course of temperature in deeper parts of lakes. The distribution of temperature is of more complicated character there - not dependent particularly on air temperature, but also on morphometric parameters, groundwater supply, etc. Issues concerning oxygen should be discussed in an analogical way. The dominant decreasing tendency of DO is considered unfavourable. It suggests the deterioration of the trophic status of lakes. Its concentration is strongly dependent on water temperature. The correlation was only evident in the epilimnion zone, where in the majority of cases an increase in temperature corresponded to a decrease in oxygen concentration. In deeper parts of water, the pattern was not recorded. Such a situation was related to both reduced oxygen supply to the lowest sectors of lakes as a result of the development of a thermocline, and mineralisation processes occurring on the bottom.

DO and temperature measurements conducted over several years in depth profiles of the studied lakes constitute valuable information on the current transformations of the environment in this part of Europe. In the future, the information can provide the basis for long-term analyses over the next decades, enriching global knowledge on these parameters of water ecosystems.

\section{References}

[1] Terzhevik A, Golosov S, Palshin N, Mitrokhov A, Zdorovennov R, Zdorovennova G, et al. Some features of the thermal and dissolved oxygen structure in boreal, shallow ice-covered Lake Vendyurskoe, Russia. Aquat Ecol. 2009;43(3):617-627. DOI: 10.1007/s10452-009-9288-x.

[2] Borowiak D, Nowiński K, Barańczuk J, Marszelewski W, Skowron R, Solarczyk A. Relationship between areal hypolimnetic oxygen depletion rate and the trophic state of five lakes in northern Poland. Limnol Rev. 2011;11(4):135-142. DOI: 10.2478/v10194-011-0035-z.

[3] Williams RJ, Boorman DB. Modelling in-stream temperature and dissolved oxygen at sub-daily time steps: An application to the River Kennet, UK. Sci Total Environ. 2012;423:104-110. DOI: 10.1016/j.scitotenv.2012.01.054.

[4] Feuchtmayr H, Moran R, Hatton K, Connor L, Heyes T, Moss B, et al. Global warming and eutrophication: Effects on water chemistry and autotrophic communities in experimental hypertrophic shallow lake mesocosms. J Appl Ecol. 2009;46(3):713-723. DOI: 10.1111/j.1365-2664.2009.01644.x. 
[5] Sereda J, Bogard M, Hudson J, Helps D, Dessouki T. Climate warming and the onset of salinization: Rapid changes in the limnology of two northern plains lakes. Limnologica. 2011;41(1):1-9. DOI: 10.1016/j.limno.2010.03.002.

[6] Simčič T, Germ M. Increased temperature due to global warming alters the respiratory potential in aquatic organisms from an oligotrophic lake. Int Rev Hydrobiol. 2010;95(4-5):370-382. DOI: 10.1002/iroh.201011213.

[7] Wojtal-Frankiewicz A. The effects of global warming on Daphnia spp. population dynamics: a review. Aquat Ecol. 2012;46:37-53. DOI: 10.1007/s10452-011-9380-x.

[8] Kao YC, Madenjian CP, Bunnell DB, Lofgren BM, Perroud M. Temperature effects induced by climate change on the growth and consumption by salmonines in Lakes Michigan and Huron. Environ Biol Fish. 2015;98(4):1089-1104. DOI: 10.1007/s10641-014-0352-6.

[9] Choiński A, Ptak M, Skowron R, Strzelczak A. Changes in ice phenology on polish lakes from 1961-2010 related to location and morphometry. Limnologica. 2015;53:42-49. DOI: 10.1016/j.limno.2015.05.005.

[10] Ejankowski W, Lenard T. Climate driven changes in the submerged macrophyte and phytoplankton community in a hard water Lake, Limnologica. 2015;52:59-66. DOI: 10.1016/j.limno.2015.03.003.

[11] Pełechata A, Pełechaty M, Pukacz A. Winter temperature and shifts in phytoplankton assemblages in a small Chara-lake. Aquat Bot. 2015;124:10-18. DOI: 10.1016/j.aquabot.2015.03.001.

[12] Yue S, Pilon P, Phinney B, Cavadias G. The influence of autocorrelation on the ability to detect trend in hydrological series. Hydrol Process. 2002;16(9):1807-1829. DOI: 10.1002/hyp.1095.

[13] Bronaugh D, Werner A. Zhang + Yue-Pilon trends package. R package version 0.10-1. Pacific Climate Impacts Consortium; 2013. https://CRAN.R-project.org/package=zyp.

[14] Wrzesiński D, Choiński A, Ptak M. Effect of the North Atlantic Oscillation on the thermal characteristics of lakes in Poland. Acta Geophys. 2015;63(3):863-883. DOI: 10.1515/acgeo-2015-0001.

[15] Nōges T, Tuvikene L, Nōges P. Contemporary trends of temperature, nutrient loading, and water quality in large Lakes Peipsi and Vōrtsjärv, Estonia. Aquat Ecosyst Health. 2010;(13):143-153. DOI: $10.1080 / 14634981003788987$.

[16] Naumenko MA, Guzivaty VV, Karetnikov SG. Climatic trends of the water surface temperature in Lake Ladoga during ice-free periods. Dokl Earth Sci. 2006;409(5):750-753. DOI: 10.1134/S1028334X06050163.

[17] George DG, Hewitt DP, Jennings E, Allott N, McGinnity P. The impact of changes in the weather on the surface temperatures of Windermere (UK) and Lough Feeagh (Ireland). In: Water in Celtic countries: quantity, quality and climatic variability. Proc Fourth Inter-Celtic Colloquium on Hydrology and Management of Water Resources, Guimaraes, Portugal, July 2005; IAHS Publications. 2007;310:86-93. http://iahs.info/uploads/dms/13792.13-86-93-IC310-22-Glen-George.pdf.

[18] Adrian R, O'Reilly CM, Zagarese H, Baines SB, Hessen DO, Keller W, et al. Lakes as sentinels of climate change. Limnol Oceanogr. 2009;54(6(2)):2283-2297. DOI: 10.4319/lo.2009.54.6_part_2.2283.

[19] Hampton SE, Izmest'eva LR, Moore MV, Katz SL, Dennis B, Silow EA. Sixty years of environmental change in the world's largest freshwater lake - Lake Baikal, Siberia. Glob Change Biol. 2008;(14):1947-1958. DOI: 10.1111/j.1365-2486.2008.01616.x.

[20] Huang A, Rao YR, Zhang W. On recent trends in atmospheric and limnological variables in Lake Ontario. J Climate. 2012;25(17):5807-5816. DOI: 10.1175/JCLI-D-11-00495.1.

[21] Skowron R. Zróżnicowanie i zmienność wybranych elementów reżimu termicznego wody w jeziorach na niżu polskim (The Differentation and the Changeability of Choin Elements of the Thermal Regime of Water in Lakes on Polish Lowland). Toruń: Wyd Nauk UMK; 2011.

[22] Zhang Y. Effect of climate warming on lake thermal and dissolved oxygen stratifications: a review. Adv Water Sci. 2015;26(1):130-139. DOI: 10.14042/J.CNKI.32.1309.2015.01.017.

[23] Antonopoulos VZ, Gianniou SK. Simulation of water temperature and dissolved oxygen distribution in Lake Vegoritis, Greece. Ecol Model. 2003;160:39-53. DOI: 10.1016/S0304-3800(02)00286-7.

[24] Marszelewski W. Zmiany koncentracji tlenu w jeziorach Pojezierza Mazurskiego (Changes in oxygen concentrations in the Mazurian Lakeland). In: Wpływ antropopresji na jeziora. Choinski A, editor. Poznań-Bydgoszcz: Wyd. Homini; 1997.

[25] Poleszczuk G, Svobodová Z, Bucior-Kwaczyńska A, Miller T. Turkusowe Lake (Wolin Island, Poland) surface waters quality changes in years 1986-2010. Ecol Chem Eng S. 2014;21(2):201-214. DOI: 10.2478/eces-2014-0016.

[26] Sidoruk M, Potasznik A. Spatial distribution of lead, zinc and chromium in the bottom deposits of Lake Sunia. Ecol Chem Eng S. 2015;22(1):243-253. DOI: 10.1515/eces-2015-0014.

[27] Sobczyński T, Joniak T. Co zagraża ekosystemowi Jeziora Góreckiego? (What threatens the ecosystem of Lake Góreckie?) In: Walna B, Kaczmarek L, Lorenc M, Dondajewska R, editors. Wielkopolski Park Narodowy w badaniach przyrodniczych, Poznań-Jeziory: Uniwersytet im. A. Mickiewicza w Poznaniu. Stacja Ekologiczna w Jeziorach; 2009. 
[28] Biedka P. Sezonowe zmiany stężenia tlenu i potencjału oksydoredukcyjnego w hypolimnionach wybranych jezior Pojezierza Suwalsko-Augustowskiego (Seasonal changes of hypolimnetic oxygen concentration and redox potential in selected lakes of Suwalsko-Augustowskie Lakeland). Infrastrukt Ekol Terenów Wiejskich. 2012;3(1):225-232. bwmeta1.element.agro-10c698a3-f124-4ec1-856e-015ae4744a05.

[29] Arnott SE, Keller B, Dillon PJ, Yan N, Paterson M, Findlay D. Using temporal coherence to determine the response to climate change in boreal shield lakes. Environ Monit Assess. 2003;88:365-388. DOI: 10.1023/A:1025537628078.

[30] Gerten D, Adrian R. Differences in the persistency of the North Atlantic Oscillation signal among lakes. Limnol Oceanogr. 2001;46(2):448-455. DOI: 10.4319/lo.2001.46.2.0448. 